\title{
The Effect of Steam Flaked or Dry Ground Corn and Supplemental Phytic Acid on Nitrogen Partitioning in Lactating Cows and Ammonia Emission from Manure
}

\author{
K. M. Burkholder, ${ }^{*}$ A. D. Guyton, J. M. McKinney, and K. F. Knowlton \\ Department of Dairy Science, \\ Virginia Polytechnic Institute and State University, Blacksburg 24061
}

\section{ABSTRACT}

The effect of starch source and supplemental phytic acid (PA) on $\mathrm{N}$ partitioning and excretion and ammonia volatilization from dairy manure was evaluated with 8 midlactation cows. Cows were randomly assigned to treatments in replicated $4 \times 4$ Latin squares with four 18 -d periods. Diets were $61 \%$ forage, $25 \%$ starch, $17.2 \%$ crude protein, and $31 \%$ neutral detergent fiber and included dry ground corn (DG) or steam flaked corn (SF) with no supplemental P $(\mathrm{L} ; 0.34 \% \mathrm{P})$ or supplemental purified $\mathrm{PA}(0.45 \% \mathrm{P})$ to provide additional $\mathrm{P}$ from a non-mineral source. Total collection of milk, urine, and feces was conducted on d 16 to 18 of each period. Cows fed SF had lower dry matter (DM) intakes than those fed DG, which, in addition to increased starch digestibility and ruminal fermentation, contributed to higher DM digestibility. Cows fed SF had reduced feces and urine excretion compared with cows fed DG. Also, N intake for cows fed SF was lower, and $\mathrm{N}$ digestibility was higher, compared with cows fed DG; therefore, $\mathrm{N}$ excretion in both feces and urine was reduced in these cows. Despite the differences in DM intake, lactation performance was not affected by starch sources. Therefore, the efficiency of $\mathrm{N}$ utilization increased with $\mathrm{SF}$. Addition of PA did not affect $\mathrm{N}$ intake or utilization. Feces and urine were subsampled from each cow, and wet feces and urine were mixed in sealed chambers in the proportions excreted. Ammonia volatilization was measured for $36 \mathrm{~h}$ using acid traps sampled on a planned time course. Nitrogen at time zero $\left(\mathrm{A}_{0}\right)$, rate of ammonia emission $(\mathrm{k})$, and residual $\mathrm{N}(\mathrm{R})$ were calculated using the exponential decay model $\mathrm{A}_{\mathrm{t}}=\mathrm{A}_{\mathrm{o}} \mathrm{e}^{-\mathrm{kt}}+$ $R$. Rate of ammonia loss from mixed feces and urine was lower from cows fed SF than from those fed DG. Altering dietary starch source to improve nutrient di-

Received July 24, 2003.

Accepted April 27, 2004.

Corresponding author: K. F. Knowlton; e-mail: Knowlton@vt.edu.

*Current address: Department of Animal Sciences, Purdue University, West Lafayette, IN 47907. gestibility and to reduce $\mathrm{N}$ excretion by lactating cows may provide opportunity to reduce ammonia losses from manure.

(Key words: steam flaked corn, ammonia emission, nitrogen excretion)

Abbreviation key: $\mathbf{D G}=$ dry ground corn, $\mathbf{L}=$ low $\mathrm{P}$, $\mathbf{P A}=$ phytic acid, $\mathbf{S F}=$ steam flaked corn .

\section{INTRODUCTION}

Nitrogen contamination of ground and surface water and air pollution caused by ammonia emission are of environmental concern. Sources of $\mathrm{N}$ contamination include atmospheric $\mathrm{N}$, fertilizer used in commercial and suburban settings, agricultural waste, and human sewage. Nitrogen can enter the farm in feed, fertilizer, and legume fixation and may be exported in product (milk, meat, or cash crops) or may be lost to the environment (via direct deposition in surface water, leaching, runoff, ammonia volatilization, or denitrification; Kohn et al., 1997).

Nitrogen contamination of surface water may cause algae blooms, which shade aquatic vegetation, reducing photosynthetic activity. Also, decomposition of algae consumes dissolved oxygen in the water (eutrophication), which impairs survival and productivity of fish, clams, oysters, crabs, and other aquatic animal life. When $\mathrm{N}$ in manure or commercial fertilizer is applied to land in excess of crop uptake, contamination of ground water via nitrate leaching may occur. Nitrate in drinking water is converted to nitrite $\left(\mathrm{NO}_{2}^{-}\right)$in the human digestive tract, which can replace oxygen in hemoglobin, resulting in cyanosis, or oxygen starvation, especially in infants.

Concentrated animal agriculture may affect air quality as well as water quality. After excretion, the organic substrate in solid and liquid animal waste is subject to microbial conversion to microbial biomass and gases, including ammonia. Ammonia volatilization from livestock waste may increase air concentrations of ammonia in animal facilities, which is detrimental to the health of farm workers and animals. Current Occupa- 
tional Safety and Health Administration standards limit exposure of farm workers to ammonia to an 8$\mathrm{h}$ time-weighted average ambient concentration of 50 ppm. Ammonia is classified as a hazardous substance in the Comprehensive Environmental Response, Compensation, and Liability Act (a.k.a. Superfund), which requires monitoring and reporting of ammonia releases from point sources exceeding $45.4 \mathrm{~kg} / \mathrm{d}$ (National Research Council, 2003).

Ammonia volatilization also increases atmospheric $\mathrm{N}$ fallout, contributing to eutrophication. Although ammonia is a highly soluble gas with a short atmospheric residence time, its accumulation in the atmosphere is of concern because ammonia reacts with acidic gases such as sulfur dioxide $\left(\mathrm{SO}_{2}\right)$ in the atmosphere to form ammonium salts. These salts return to soil in rainfall and release nitric and sulfuric acid when oxidized in soil (Apsimon et al., 1987; Likens et al., 1996). The fine particles created by the reaction of ammonia with acidic gases are also classified as $\mathrm{PM}_{2.5}$, a criteria pollutant listed in the National Ambient Air Quality Standards. The Environmental Protection Agency estimates that $71 \%$ of national ammonia emissions are from animal agriculture (EPA, 1998).

Refining diets fed to dairy cows can reduce $\mathrm{N}$ excretion and N losses from dairy farms. Kohn et al. (1997) developed a model of $\mathrm{N}$ management on dairy farms and conducted sensitivity analyses to determine the relative importance of herd nutrition, manure management, and crop selection on $\mathrm{N}$ losses. Improvements in herd nutrition to increase conversion of feed $\mathrm{N}$ to product resulted in the greatest reduction in potential $\mathrm{N}$ losses from farms (Kohn et al., 1997). Altering dietary protein content may also affect ammonia emission from manure. James et al. (1999) found that decreasing N intake of Holstein heifers by $14 \%$ resulted in a $28.1 \%$ reduction in ammonia loss from manure (mixed feces and urine). Significant decreases in concentrations of urinary urea $\mathrm{N}$ and total $\mathrm{N}$ and in proportions of $\mathrm{N}$ excreted in the urine were also observed (James et al., 1999). Frank and Swensson (2002) found that manure from dairy cows fed low protein diets emitted significantly less ammonia than manure from cows fed high protein diets. Finally, Marini and Van Amburgh (2003) observed linear decreases in excretion of both urea $\mathrm{N}$ and total urinary $\mathrm{N}$ in heifers fed diets with reduced $\mathrm{N}$ content.

Although the dietary content of nutrients other than protein do affect $\mathrm{N}$ excretion, little published research exists on the effect of other dietary factors on ammonia volatilization from manure. Starch availability affects $\mathrm{N}$ retention and excretion in lactating cows by altering ruminal microbial $\mathrm{N}$ metabolism (Clark et al., 1992) and also by changing the amount of starch fermented in the large intestine. Increased large intestinal starch fermentation increases the recycling of blood urea $\mathrm{N}$ into microbial $\mathrm{N}$, causing an increase in fecal N excretion (Orskov et al., 1970; Wilkerson et al., 1997; Knowlton et al., 1998). The effect of starch availability on ammonia volatilization from manure is unknown. Dietary $\mathrm{P}$ content affects ruminal fermentation, but little work has been done to assess its effect on $\mathrm{N}$ digestion and metabolism in cows. The overall objective of the study was to evaluate the effect of starch source, dietary phytate $\mathrm{P}$ content, and their interaction on nutrient partitioning and excretion in lactating dairy cows. In this manuscript, the effects of treatment on $\mathrm{N}$ digestion, partitioning, and excretion and ammonia loss from manure are reported.

\section{MATERIALS AND METHODS}

\section{Cows and Diets}

Eight midlactation Holstein cows $(113 \pm 46$ DIM $)$ were assigned randomly to experimental diets containing steam flaked corn (SF) or dry ground corn (DG) corn, with one of 2 concentrations of dietary P. Diets were formulated to meet the nutrient requirements of the cow according to NRC guidelines (1989). Four of the cows were ruminally cannulated with plastisol cannulas (10.2 cm i.d.; Bar Diamond Cannula, Bar Diamond Inc., Parma, ID). This experiment was conducted under approval from the Virginia Tech Animal Care Committee.

Treatment diets contained $61 \%$ forage. The low $\mathrm{P}$ diets (L) (DG-L, SF-L) were formulated to contain $0.34 \%$ P. Purified phytic acid (PA) was added to the basal diets to create the high $\mathrm{P}$ diets (DG-PA, SF-PA). Flake density of the SF was $386 \mathrm{~g} / \mathrm{L}$. Ingredient composition of the diets is listed in Table 1.

Groups were balanced for parity and previous mature equivalent milk yield. A total of 2 cows missed one collection period each because of clinical mastitis. The first of these cows missed Period 1 while on the DG-PA treatment. This cow's milk yield returned to normal by d 2 of Period 2, and she was collected as usual in Periods 2,3 , and 4 . The other mastitic cow missed Period 4 while on the SF-L treatment.

\section{Experimental Design and Sampling}

Total collection study. Experimental design, treatment rations, feeding protocol, and collection and sampling of feed refusals, feces, urine, and milk were described by Guyton et al. (2003). Briefly, 8 cows were grouped by calving date and previous milk yield and assigned to one of $2,4 \times 4$ Latin squares. Each experimental period lasted $18 \mathrm{~d}$. Cows were fed in Calan doors 
Table 1. Ingredient composition of diets.

\begin{tabular}{|c|c|c|c|c|}
\hline & \multicolumn{2}{|c|}{$\begin{array}{l}\text { Dry ground } \\
\text { corn }\end{array}$} & \multicolumn{2}{|c|}{$\begin{array}{l}\text { Steam flaked } \\
\text { corn }\end{array}$} \\
\hline & Low $\mathrm{P}$ & PA & Low $\mathrm{P}$ & $\mathrm{PA}$ \\
\hline Diet ingredient & \multicolumn{4}{|c|}{ (\% of diet DM) } \\
\hline Alfalfa silage & 46.1 & 45.8 & 46.1 & 45.8 \\
\hline Corn silage & 15.4 & 15.3 & 15.4 & 15.3 \\
\hline Ground corn & 28.8 & 28.7 & 0.0 & 0.0 \\
\hline Steam flaked corn & 0.0 & 0.0 & 28.8 & 28.7 \\
\hline Concentrate mixture & 9.7 & 10.2 & 9.7 & 10.2 \\
\hline Concentrate ingredient & \multicolumn{4}{|c|}{ (\% of concentrate DM) } \\
\hline Soybean meal, $48 \% \mathrm{CP}$ & 42.2 & 40.1 & 42.2 & 40.1 \\
\hline Expeller soybean meal $^{1}$ & 28.1 & 26.7 & 28.1 & 26.7 \\
\hline Mineral $\operatorname{mix}^{2}$ & 18.5 & 17.6 & 18.5 & 17.6 \\
\hline Sodium bicarbonate & 5.3 & 5.0 & 5.3 & 5.0 \\
\hline Limestone & 4.8 & 4.6 & 4.8 & 4.6 \\
\hline Salt (white) & 1.1 & 1.0 & 1.1 & 1.0 \\
\hline Phytic acid & 0.0 & 5.0 & 0.0 & 5.0 \\
\hline
\end{tabular}

${ }^{1}$ Soyplus; West Central Soy, Ralston, IA.

${ }^{2}$ Each $\mathrm{kg}$ contained $25 \mathrm{~g} \mathrm{Mg}, 10 \mathrm{mg}$ Co, $500 \mathrm{mg} \mathrm{Cu}, 40 \mathrm{mg} \mathrm{I}, 2.25$ g Mn, $15 \mathrm{mg}$ Se, $2.5 \mathrm{~g} \mathrm{Zn}, 331,000$ IU vitamin A, 110,200 IU vitamin $\mathrm{D}$, and $1323 \mathrm{IU}$ vitamin $\mathrm{E}$.

for the first $14 \mathrm{~d}$ of each period and were moved to individual stalls on d 15 for total collection of feces, urine, and milk. On d 15, a sterile Foley urine catheter (22 French, 75 cc; C.R. Bard, Inc., Covington, GA) was inserted into the urethra for total collection of urine. All excreted urine, feces, and milk were collected on d 16,17 , and 18. Urine was weighed at 4 -h intervals. Except for subsamples collected for the ammonia volatilization study (detailed below), urine was acidified (22 $\mathrm{mL}$ of $6 \mathrm{~N} \mathrm{HCI} / \mathrm{kg}$ of urine), thoroughly mixed and subsampled daily. All excreted feces were collected at 4-h intervals and stored in a sealed container then weighed, thoroughly mixed, and subsampled daily.

Ammonia volatilization study. Samples of feces and unacidified urine were collected on d 18 of each collection period by subsampling the total excreta produced that day. Fecal samples (wet) and unacidified urine (in sterile containers) from each cow were immediately transported to the laboratory for use in the ammonia volatilization study. Total feces and urine excretion data from d 18 of each period were used to determine the urine:feces excretion ratio (wet basis) for each animal. Feces and urine from each cow were mixed in the proportions excreted in a $400-\mathrm{mL}$ sealed chamber, forming a slurry to characterize potential ammonia volatilization. Duplicate chambers were prepared for each animal. Chambers were prepared within $30 \mathrm{~min}$ of feces and urine sampling.

Chamber lids were fitted with 3 airtight junctions to Teflon tubing ( $0.32 \mathrm{~cm}$ i.d.). Inlet air to the samples (25 psi) was filtered through 3 anhydrous $\mathrm{CaSO}_{4}$ columns (W. A. Hammond Drierite Co., Xenia, $\mathrm{OH}$ ) to remove

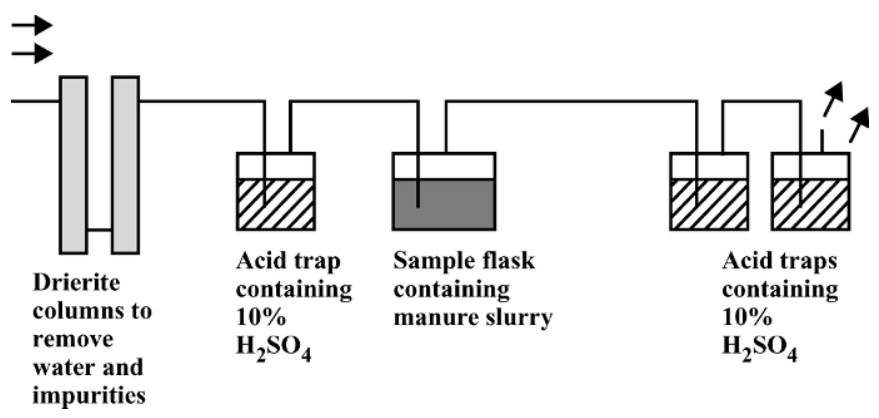

Figure 1. Schematic diagram of the apparatus used in the ammonia volatilization experiment. Arrows indicate the direction of air flow.

water and impurities and through an acid trap containing $3.6 \mathrm{~N} \mathrm{H}_{2} \mathrm{SO}_{4}$ to absorb ammonia. A manifold was used to divert the air stream into sample chambers containing the slurries. Exhaust air from each sample container was delivered through Teflon tubing to 2 consecutive $250-\mathrm{mL}$ acid traps, each containing $125 \mathrm{~mL}$ $3.6 \mathrm{~N} \mathrm{H}_{2} \mathrm{SO}_{4}$ (Figure 1). Samples were collected on a planned time course at $0.5,1,1.5,2,2.5,3,4,5,6,7$, $8,9,12,15,18,24,30$, and $36 \mathrm{~h}$ following mixing of urine and feces. Samples from the acid traps were sealed and refrigerated until analysis.

\section{Laboratory Analysis and Calculations}

Total collection study. Analysis of feed, feed refusals, and urine and feces samples were described by Guyton et al. (2003). Nutrient composition of the diets is listed in Table 2. Dried ground corn and SF were not from the same source, so the effects of starch source (corn grain processing) might have been confounded with differences in corn grain genotype, growing environment, or harvest.

Ammonia volatilization study. Samples from the acid traps were analyzed for ammonia content using an automated ion analyzer (Virginia Tech Environmental Quality Laboratory, Blacksburg). Nitrogen at time zero, rate of ammonia $\mathrm{N}$ loss, and residual $\mathrm{N}$ were calculated using the exponential decay model $A_{t}=A_{o} e^{-k t}+R$, where $A_{t}=N$ remaining in sample chamber at time $t$, calculated as $\mathrm{N}$ in sample chamber at time zero minus cumulative $\mathrm{N}$ loss; $\mathrm{A}_{0}=\mathrm{N}$ in sample chamber at time zero $(\mathrm{mg}) ; \mathrm{k}=$ rate of $\mathrm{N}$ loss from chamber $(\% / \mathrm{h}) ; \mathrm{t}=$ time (h); and $\mathrm{R}=$ residual $\mathrm{N}$ in chamber at $36 \mathrm{~h}(\mathrm{mg})$.

\section{Statistical Analysis}

All data were statistically analyzed using PROC MIXED of SAS (SAS, 1999) with the model

$$
\mathrm{Y}_{\mathrm{ijkl}}=\mu+\mathrm{G}_{\mathrm{i}}+\mathrm{C}_{\mathrm{j}}(\mathrm{G})_{\mathrm{i}}+\mathrm{D}_{\mathrm{k}}+\mathrm{S}_{\mathrm{l}}+\mathrm{P}_{\mathrm{m}}+(\mathrm{S} * \mathrm{P})_{\mathrm{lm}}+\mathrm{e}_{\mathrm{ijk} \mathrm{k}}
$$


Table 2. Nutrient composition of diets.

\begin{tabular}{|c|c|c|c|c|c|c|c|c|}
\hline & \multicolumn{2}{|c|}{ Dry ground corn } & \multicolumn{2}{|c|}{ Steam flaked corn } & \multirow[b]{2}{*}{ SEM } & \multicolumn{3}{|c|}{$P<$} \\
\hline & Low $\mathrm{P}$ & PA & Low $\mathrm{P}$ & PA & & Starch & $\mathrm{P}$ & Starch $\times P$ \\
\hline & \multicolumn{8}{|c|}{$\longrightarrow(\%$ of $\operatorname{diet} \mathrm{DM})$} \\
\hline NDF & 31.7 & 31.5 & 31.7 & 31.4 & 0.46 & 0.91 & 0.61 & 0.90 \\
\hline $\mathrm{ADF}$ & 21.5 & 21.2 & 21.8 & 21.6 & 0.48 & 0.51 & 0.66 & 0.89 \\
\hline Ash & 7.65 & 7.91 & 7.55 & 7.84 & 0.08 & 0.31 & 0.05 & 0.81 \\
\hline $\mathrm{CP}$ & 17.2 & 17.2 & 17.1 & 17.1 & 0.20 & 0.50 & 0.83 & 0.80 \\
\hline $\mathrm{P}$ & 0.35 & 0.45 & 0.31 & 0.42 & 0.01 & 0.01 & 0.01 & 0.79 \\
\hline $\mathrm{Ca}$ & 0.78 & 0.81 & 0.78 & 0.82 & 0.02 & 0.62 & 0.04 & 0.85 \\
\hline $\mathrm{Mg}$ & 0.33 & 0.35 & 0.33 & 0.34 & 0.01 & 0.67 & 0.29 & 0.84 \\
\hline Starch & 24.5 & 24.4 & 25.1 & 24.9 & 0.42 & 0.17 & 0.67 & 0.91 \\
\hline
\end{tabular}

where

$$
\begin{aligned}
\mu & =\text { overall mean, } \\
\mathrm{G}_{\mathrm{i}} & =\text { random effect of square }(\mathrm{i}=1 \text { to } 2), \\
\mathrm{C}_{\mathrm{j}}(\mathrm{G})_{\mathrm{i}} & =\text { random effect of cow within square }(\mathrm{j}=1 \\
& \text { to } 4), \\
\mathrm{D}_{\mathrm{k}} & =\text { fixed effect of period }(\mathrm{k}=1 \text { to } 4), \\
\mathrm{S}_{1} & =\text { fixed effect of starch source }(1=1 \text { to } 2), \\
\mathrm{P}_{\mathrm{m}} & =\text { fixed effect of } \mathrm{P} \text { source }(\mathrm{m}=1 \text { to } 2), \\
(\mathrm{S} * \mathrm{P})_{\mathrm{lm}} & =\text { effect of interaction of } \mathrm{S}_{\mathrm{l}} \text { and } \mathrm{P}_{\mathrm{m}}, \text { and } \\
\mathrm{e}_{\mathrm{ijk} \mathrm{m}} & =\text { residual error. }
\end{aligned}
$$

Residual error was used to test main effects and interactions. Differences were declared significant at $P<$ 0.05 , and trends were declared at $P<0.10$. Results are reported as least square means.

\section{RESULTS AND DISCUSSION}

Feed intake, milk yield, starch digestion, ruminal fermentation, and $\mathrm{P}$ digestion and partitioning were the focus of a concurrent aspect of this experiment, and these data have been reported previously (Guyton et al., 2003). Briefly, cows fed SF had a lower DMI compared with cows fed DG ( 24.0 vs. $25.8 \mathrm{~kg} / \mathrm{d})$, but starch source did not affect milk yield (mean $=33.6 \mathrm{~kg} / \mathrm{d}$ ). Cows fed SF had higher apparent total tract DM digestibility and total tract starch digestibility than those fed DG.

\section{Manure Production and Composition}

Effect of starch source. Cows fed SF had reduced excretion of feces DM and urine when compared with cows fed DG (Table 3). Cows fed SF had wetter feces (Table 4), so feces production on a wet basis was not affected by treatment. Cows fed SF tended to have lower total water excretion (fecal water + urine; $P<0.07$ ) than did cows fed DG, and cows fed SF also excreted less total manure (urine + feces, wet basis). The concentration of $\mathrm{N}$ in feces was higher in cows fed SF (Table
4) because the diet DM was more digestible than the DG diet.

The decrease in feces DM excretion with the SF diet was probably due to the decrease in DMI and improved starch digestibility observed (Guyton et al., 2003). Axe et al. (1987) reported an increase in fecal DM excretion when steers were fed a sorghum-based diet compared with steers fed a wheat-based diet, but there was no reported effect on DMI. In contrast, Streeter et al. (1989) observed an increase in DMI and feces excretion when Angus-Hereford heifers were fed diets containing high moisture corn in place of DG.

There are no other published data on the effect of starch source on urine excretion in lactating cows. The observed change in urine output and total water excretion may be related to the effect of starch source on DMI (Guyton et al., 2003), which might have affected water intake. No measurements of water consumption were obtained in this experiment, but Woodford et al. (1984) observed a significant increase in water consumption (35.6 to $65.2 \mathrm{~L} / \mathrm{d})$ when DMI increased in Holstein cows (9.6 to $16.2 \mathrm{~kg} / \mathrm{d}$ ). Murphy et al. (1983) also reported a positive relationship between DMI and water consumption.

Effect of PA supplementation. Supplementation with PA did not affect excretion of feces, but cows fed PA excreted more urine $(+1.9 \mathrm{~kg} / \mathrm{d})$ than did cows fed the L diet (Table 3 ). No other experiments have reported an effect of dietary $\mathrm{P}$ source or content on urine excretion. The effect of PA supplementation on urine excretion is likely an indirect effect, but the biological mechanism is unclear. Diets were formulated to contain the same $\mathrm{Na}$ and $\mathrm{K}$ content with the same quantities of salt and other mineral supplements provided.

Cows fed PA tended to excrete drier feces (Table 4), which may be related to the observation of increased urine excretion, as total water excretion (urine + fecal water) was similar in cows fed the L and PA diets.

\section{N Intake, Digestion, and Excretion}

Effect of starch source. Because of the increase in DMI, N intake was higher in cows fed DG than in cows 
Table 3. Effect of starch source and supplemental dietary phytic acid (PA) on feed intake and digestibility and manure excretion in lactating Holstein cows.

\begin{tabular}{|c|c|c|c|c|c|c|c|c|}
\hline & \multicolumn{2}{|c|}{ Dry ground corn } & \multicolumn{2}{|c|}{ Steam flaked corn } & \multirow[b]{2}{*}{ SEM $^{1}$} & \multicolumn{3}{|c|}{$P<$} \\
\hline & Low $\mathrm{P}$ & $\mathrm{PA}$ & Low $\mathrm{P}$ & PA & & Starch & $\mathrm{P}$ & Starch $\times P$ \\
\hline $\mathrm{n}$ & 8 & 7 & 7 & 8 & & & & \\
\hline $\mathrm{DMI},{ }^{2} \mathrm{~kg} / \mathrm{d}$ & 25.1 & 26.4 & 24.2 & 23.7 & 0.95 & 0.03 & 0.63 & 0.25 \\
\hline Apparent DM digestibility ${ }^{2}$ & 66.9 & 67.1 & 70.4 & 69.4 & 0.94 & 0.01 & 0.63 & 0.54 \\
\hline Feces, kg DM/d & 8.30 & 8.62 & 7.15 & 7.24 & 0.28 & 0.01 & 0.31 & 0.56 \\
\hline Feces \% DM & 13.8 & 14.7 & 12.2 & 12.7 & 0.44 & 0.01 & 0.07 & 0.57 \\
\hline Feces, kg/d (wet) & 59.9 & 59.8 & 59.1 & 58.0 & 2.95 & 0.32 & 0.65 & 0.72 \\
\hline Urine, kg/d & 25.2 & 26.7 & 21.9 & 24.1 & 1.31 & 0.01 & 0.02 & 0.59 \\
\hline Total excreta, kg/d (wet) & 85.1 & 86.4 & 81.0 & 82.1 & 2.94 & 0.02 & 0.44 & 0.96 \\
\hline Fecal water excretion, ${ }^{3} \mathrm{~kg} / \mathrm{d}$ & 51.6 & 51.1 & 51.9 & 50.8 & 2.72 & 0.99 & 0.49 & 0.76 \\
\hline Total water excretion, ${ }^{4} \mathrm{~kg} / \mathrm{d}$ & 76.8 & 77.8 & 73.8 & 74.9 & 2.72 & 0.07 & 0.48 & 1.0 \\
\hline
\end{tabular}

${ }^{1}$ Unequal $\mathrm{n}$; largest SEM ( $\mathrm{n}=7$ ) reported.

${ }^{2} \mathrm{DMI}$ and DM digestibility data originally reported in Guyton et al. (2003).

${ }^{3}$ Fecal water excretion calculated as wet feces $(\mathrm{kg} / \mathrm{d}) \times(1-\% \mathrm{DM}$ of feces $)$.

${ }^{4}$ Total water excretion calculated as fecal water plus urine.

fed SF (Table 5; 709.4 vs. $656.1 \mathrm{~g} / \mathrm{d})$. Zinn et al. (1995) and Theurer et al. (1999) reported no change in $\mathrm{N}$ intake when steers were fed diets containing SF instead of dry rolled corn. Plascencia and Zinn (1996), however, observed an increase in DMI and N intake when cows were fed SF compared with dry rolled corn.

Feeding SF corn tended to improve apparent $\mathrm{N}$ digestibility $(P<0.07)$ and increased the proportion of consumed $\mathrm{N}$ captured in milk, although no effects were observed on milk $\mathrm{N}$ secretion and $\mathrm{N}$ balance (Table 5). An increase in total tract $\mathrm{N}$ digestibility was observed when steers and lactating cows were fed diets containing SF in place of dry rolled corn (Zinn et al., 1995; Plascencia and Zinn, 1996) or high moisture corn in place of dry corn (Knowlton et al., 1998). Nocek (1987) reported increased in situ $\mathrm{N}$ digestibility in cows fed high moisture ear corn compared with those fed dried ear corn, dried shelled corn, or high moisture shelled corn.

Fecal, urinary, and total excretion of $\mathrm{N}$ was higher in cows fed DG than in cows fed SF (Table 5). The increased fecal $\mathrm{N}$ excretion in cows fed DG was due to the increase in $\mathrm{N}$ intake and decreased $\mathrm{N}$ digestibility. This change in fecal $\mathrm{N}$ excretion with starch source appears contradictory to the decreased fecal $\mathrm{N}$ concen- tration observed with DG (Table 4). The contradiction is explained by the offsetting changes in digestibility and fecal water content. Feces were drier in cows fed DG, DM digestibility lower, and fecal DM excretion higher. Therefore, total fecal $\mathrm{N}$ excretion $(\mathrm{g} / \mathrm{d})$ was higher in cows fed the DG diet than in cows fed SF despite reduced fecal $\mathrm{N}$ concentration (\% of $\mathrm{DM})$.

The decreased urinary $\mathrm{N}$ excretion observed when cows were fed SF was likely due both to decreased N intake and increased availability of nutrients to ruminal microorganisms in steam flaked grain. Urinary $\mathrm{N}$ is made up of unused absorbed $\mathrm{N}$ from all sources (ammonia N, microbial N, or feed N). Steam flaking disrupts the protein matrix surrounding starch granules, increasing their susceptibility to rumen fermentation (Kotarski et al., 1992). Increased ruminal availability of dietary starch would increase microbial $\mathrm{N}$ efficiency in cows fed SF compared with those fed DG, reducing absorption and excretion of urea N. Our observations agree with those of Prigge et al. (1976), who reported decreased urinary $\mathrm{N}$ excretion when lambs were fed high moisture corn compared with DG.

Cows fed SF had lower MUN concentrations than did cows fed DG, again indicating a greater efficiency of $\mathrm{N}$ utilization with the SF diet (Table 5). Kohn et al. (2002)

Table 4. Effect of starch source and supplemental dietary phytic acid (PA) on manure composition.

\begin{tabular}{|c|c|c|c|c|c|c|c|c|}
\hline & \multicolumn{2}{|c|}{ Dry ground corn } & \multicolumn{2}{|c|}{ Steam flaked corn } & \multirow[b]{2}{*}{$\mathrm{SEM}^{1}$} & \multicolumn{3}{|c|}{$P<$} \\
\hline & Low $\mathrm{P}$ & $\mathrm{PA}$ & Low $\mathrm{P}$ & $\mathrm{PA}$ & & Starch & $\mathrm{P}$ & Starch $\times \mathrm{P}$ \\
\hline Feces \% DM & 13.8 & 14.7 & 12.2 & 12.7 & 0.44 & 0.01 & 0.07 & 0.57 \\
\hline Fecal N, \% DM & 3.40 & 3.32 & 3.51 & 3.41 & 0.05 & 0.03 & 0.05 & 0.83 \\
\hline Urinary N, \% (wet) & 0.58 & 0.57 & 0.58 & 0.57 & 0.03 & 0.91 & 0.75 & 0.71 \\
\hline Feces:urine & 2.18 & 2.68 & 2.47 & 2.56 & 0.25 & 0.64 & 0.15 & 0.30 \\
\hline
\end{tabular}

\footnotetext{
${ }^{1}$ Unequal $\mathrm{n}$; largest SEM $(\mathrm{n}=7)$ reported.
} 
Table 5. Effect of starch source and supplemental dietary phytic acid (PA) on $\mathrm{N}$ intake and excretion in lactating Holstein cows.

\begin{tabular}{|c|c|c|c|c|c|c|c|c|}
\hline & \multicolumn{2}{|c|}{ Dry ground corn } & \multicolumn{2}{|c|}{ Steam flaked corn } & \multirow[b]{2}{*}{$\mathrm{SEM}^{1}$} & \multicolumn{3}{|c|}{$P<$} \\
\hline & Low $\mathrm{P}$ & $\mathrm{PA}$ & Low $\mathrm{P}$ & $\mathrm{PA}$ & & Starch & $\mathrm{P}$ & Starch $\times P$ \\
\hline $\mathrm{N}$ intake, $\mathrm{g} / \mathrm{d}$ & 693.2 & 725.6 & 662.0 & 650.2 & 26.5 & 0.02 & 0.63 & 0.30 \\
\hline Feces N, g/d & 282.3 & 286.9 & 250.2 & 247.4 & 9.9 & 0.01 & 0.89 & 0.53 \\
\hline Apparent $\mathrm{N}$ digestibility $\%$ & 59.3 & 60.5 & 62.1 & 61.9 & 1.2 & 0.07 & 0.68 & 0.50 \\
\hline Urine $\mathrm{N}, \mathrm{g} / \mathrm{d}$ & 145.1 & 151.1 & 121.4 & 135.9 & 8.1 & 0.02 & 0.16 & 0.54 \\
\hline Total $\mathrm{N}$ excretion, $\mathrm{g} / \mathrm{d}$ & 427.4 & 436.5 & 372.4 & 383.3 & 11.7 & 0.01 & 0.30 & 0.93 \\
\hline Milk N, g/d & 180.3 & 187.7 & 180.3 & 184.3 & 4.5 & 0.69 & 0.18 & 0.68 \\
\hline Milk $\mathrm{N}, \%$ of $\mathrm{N}$ intake & 26.2 & 26.2 & 27.5 & 28.6 & 0.92 & 0.05 & 0.50 & 0.53 \\
\hline MUN, mg/dL & 10.2 & 9.1 & 8.7 & 8.6 & 0.50 & 0.02 & 0.13 & 0.16 \\
\hline $\mathrm{N}$ balance, $\mathrm{g} / \mathrm{d}$ & 85.4 & 99.3 & 109.2 & 82.5 & 19.1 & 0.84 & 0.71 & 0.25 \\
\hline
\end{tabular}

${ }^{1}$ Unequal n; largest SEM $(\mathrm{n}=7)$ reported.

calculated a target range of MUN concentrations in Holstein cows of 8 to $12 \mathrm{mg} / \mathrm{dL}$. The values reported in the current study are within this normal range. Milk urea $\mathrm{N}$ reflects efficiency of protein utilization and can be used as a predictor of urinary $\mathrm{N}$ excretion in dairy cattle (Jonker et al., 1998; Kauffman and St-Pierre, 2001). Jonker et al. (1998) and Kauffman and St-Pierre (2001) reported a positive, linear relationship between MUN concentration and urinary $\mathrm{N}$ excretion in lactating Holsteins and Jerseys. Dhiman et al. (2002) reported that cows fed SF had lower MUN concentrations than did cows fed DG. Prigge et al. (1976) observed that steers fed DG had higher levels of plasma urea $\mathrm{N} 2 \mathrm{~h}$ after feeding compared with steers fed high moisture corn and concluded that steers fed high moisture corn used $\mathrm{N}$ more efficiently.

Effect of PA supplementation. Supplementation with PA had no effect on $\mathrm{N}$ intake, fecal $\mathrm{N}$, apparent $\mathrm{N}$ digestibility, urinary $\mathrm{N}$, milk $\mathrm{N}$, total $\mathrm{N}$ excretion, and $\mathrm{N}$ balance (Table 5). No effects of the interaction of the starch source and phytic acid supplementation on any of these measurements were observed.

Although no other studies have reported the effect of dietary $\mathrm{P}$ content on $\mathrm{N}$ metabolism, several researchers have reported that dietary $\mathrm{P}$ affects ruminal fermentation. Hall et al. (1961) observed increased in vitro cellulose digestion with increasing $\mathrm{P}$ concentration. The increased cellulose digestion was most marked with the initial addition of $20(\mathrm{~g} \mathrm{P} / \mathrm{mL}$ of medium, and the response reached a plateau with concentrations $>60 \mu \mathrm{g} \mathrm{P} /$ $\mathrm{mL}(1.94 \mathrm{mM})$. These concentrations are below normal concentrations of $\mathrm{P}$ in ruminal fluid. In sheep, ruminal $\mathrm{P}$ concentrations ranged from 2 to $15 \mathrm{mmol} / \mathrm{L}$ as dietary $\mathrm{P}$ increased from insufficient to adequate (ShiraziBeechey et al., 1991). Beardsworth et al. (1989) observed ruminal P concentrations of $26 \mathrm{mmol} / \mathrm{L}$ in sheep fed a commercial pellet and chopped hay, and Tomas (1973) observed ruminal P concentrations of 23 to 30 $\mathrm{mmol} / \mathrm{L}$ in sheep. Together, these studies indicate that ruminal fermentation is inhibited only in animals fed diets severely deficient in $\mathrm{P}$. The positive $\mathrm{P}$ balance observed in the current study (Guyton et al., 2003) indicate that the $\mathrm{L}$ diet was not deficient in $\mathrm{P}$, so no effect on ruminal microbial protein production would be expected with the addition of supplemental P.

\section{Ammonia Emission}

Effect of starch source. Rate of ammonia loss from slurry (mixed feces and urine) was lower in cows fed $\mathrm{SF}$ than in cows fed DG, but cumulative $\mathrm{N}$ loss was highly variable and not affected by treatment (Table 6). Although there is no published research reporting rates of ammonia emission from dairy manure, others have observed that reducing $\mathrm{N}$ excretion reduces total ammonia emission. James et al. (1999) found that decreasing $\mathrm{N}$ intake of Holstein heifers by $14 \%$ reduced urinary concentrations of $\mathrm{N}$ and urea $\mathrm{N}$ and reduced the proportion of $\mathrm{N}$ excreted in urine. Total $\mathrm{N}$ lost during incubation of manure samples was not affected by diet in the heifer study of James et al. (1999), but estimated ammonia $\mathrm{N}$ loss per head, calculated from ammonia volatilization, the ratio of urine $\mathrm{N}$ in the sample, and urinary $\mathrm{N}$ excretion by the animal, was reduced by $28 \%$ in the heifers fed the low protein diet (James et al., 1999). In another study with growing heifers fed diets varying in $\mathrm{N}$ content, excess $\mathrm{N}$ was excreted in the urine as urea $\mathrm{N}$ rather than in the feces (Marini and Van Amburgh, 2003). Frank and Swensson (2002) found that manure from dairy cows fed low protein diets contained less $\mathrm{N}$ and less ammonia. When they incubated manure in a ventilated chamber, ammonia concentration in the exhaust air was significantly lower for manure from cows fed the low protein diets.

The decreased rate of ammonia loss was due either to reduced $\mathrm{N}$ in the chambers of cows fed SF (reflecting reduced total wet manure excretion) or to a change in the susceptibility of manure $\mathrm{N}$ to volatilization (e.g., a 
Table 6. Effect of starch source and supplemental dietary phytic acid (PA) on ammonia losses from manure of lactating Holstein cows.

\begin{tabular}{|c|c|c|c|c|c|c|c|c|}
\hline & \multicolumn{2}{|c|}{ Dry ground corn } & \multicolumn{2}{|c|}{ Steam flaked corn } & \multirow[b]{2}{*}{ SEM $^{1}$} & \multicolumn{3}{|c|}{$P<$} \\
\hline & Low $\mathrm{P}$ & PA & Low $\mathrm{P}$ & PA & & Starch & $\mathrm{P}$ & Starch $\times P$ \\
\hline Feces in chamber, g DM & 19.6 & 20.0 & 17.4 & 17.7 & 0.47 & 0.01 & 0.34 & 0.88 \\
\hline Initial total $\mathrm{N}$ in chamber, $\mathrm{mg}$ & 1030 & 1006 & 901 & 962 & 36.8 & 0.02 & 0.58 & 0.20 \\
\hline Urinary $\mathrm{N}, \%$ total $\mathrm{N}$ in chamber & 35.8 & 32.7 & 34.1 & 34.7 & 1.91 & 0.89 & 0.24 & 0.10 \\
\hline Rate of ammonia loss, $\% / \mathrm{h}$ & 0.14 & 0.17 & 0.15 & 0.12 & 0.01 & 0.05 & 0.89 & 0.03 \\
\hline Residual $\mathrm{N}$ in chamber, $\mathrm{mg}$ & 964.6 & 951.7 & 842.0 & 914.7 & 40.7 & 0.07 & 0.47 & 0.30 \\
\hline
\end{tabular}

${ }^{1}$ Unequal n; largest SEM $(\mathrm{n}=7)$ reported.

change in urea $\mathrm{N}$ as a proportion of total $\mathrm{N}$ excretion). Feces and urine were added to the chambers in proportions that reflected excretion of wet feces and urine by the cow. Cows fed SF excreted wetter feces than cows fed DG (Table 4), which affected the quantity of manure $\mathrm{N}$ initially placed into chambers. Equal quantities of wet feces were weighed into chambers, so the chambers containing manure from cows fed SF contained less DM and less $\mathrm{N}$ (Table 6). Therefore, less manure $\mathrm{N}$ was available for volatilization from manure from cows fed SF. This approach (feces and urine mixed on a wet excretion basis, rather than on the basis of $\mathrm{N}$ content) was used in an attempt to mimic the mixing of feces and urine on the barn floor following excretion.

Alternatively, starch source might have affected the proportion of ammonia and urea $\mathrm{N}$ in manure, affecting the susceptibility of excreted $\mathrm{N}$ to volatilization. Nitrogen in manure is in the form of ammonia $\mathrm{N}$, urea $\mathrm{N}$, and larger organic $\mathrm{N}$ compounds (undigested feed $\mathrm{N}$, endogenous $\mathrm{N}$, and microbial $\mathrm{N}$ residues). The first 2 forms of $\mathrm{N}$ are rapidly lost as ammonia; the latter is more slowly converted to ammonia. Reducing the proportion of slurry $\mathrm{N}$ that is in the form of ammonia or urea would be expected to reduce $\mathrm{N}$ volatilization. Urea $\mathrm{N}$ content of excreta and slurry was not analyzed, but the proportion of total $\mathrm{N}$ excreted that was from urine (and therefore the proportion placed in the chambers) was not affected by dietary starch source (Table 6). This result suggests that the first explanation offered (reduced ammonia emission as a result of reduced $\mathrm{N}$ in the chambers) is more relevant. These observations are, however, specific to the experimental conditions. On the farm, actual ammonia emission is also a function of moisture and $\mathrm{pH}$ of manure, ambient temperature, and wind conditions.

Effect of PA supplementation. Supplementation with PA did not affect rate of ammonia loss from manure (Table 6). The interaction of starch source and PA affected rate of ammonia emission from manure $(0.14$, $0.17,0.15$, and $0.12 \mathrm{mg} / \mathrm{h}$ for DG-L, DG-PA, SF-L, and SF-PA). The biological explanation for this interaction was not readily apparent. The lowest rates of ammonia emission were observed in the diets highest in both $\mathrm{P}$ and ruminally available starch, and the interaction did not affect other relevant measures of manure $\mathrm{N}$.

\section{CONCLUSIONS}

Cows fed SF had lower DMI than those fed DG, which, in addition to increased starch digestibility and ruminal fermentation, contributed to the higher DM digestibility. Feces and urine production were reduced with SF. Also, $\mathrm{N}$ intake for these cows was lower, and $\mathrm{N}$ digestibility was higher. These differences were associated with lower $\mathrm{N}$ excretion in both feces and urine for these cows. Despite the lower intakes, lactation performance of these cows was not affected, and, therefore, the efficiency of $\mathrm{N}$ utilization increased. The rate of ammonia emission was lower in manure from cows fed SF compared with those fed DG, because cows fed SF excreted less total $\mathrm{N}$ and had wetter feces; therefore, they had less $\mathrm{N}$ available for volatilization from the chambers. Reduced feed intake and increased nutrient digestibility associated with improved ruminal starch availability reduced $\mathrm{N}$ excretion by lactating cows and reduced ammonia emission from manure.

\section{ACKNOWLEDGMENTS}

Financial support for this project was provided by Loveland Industries (Greeley, CO) and Pennfield Corporation (Lancaster, PA). The authors appreciate the input of Carl Polan, Tim Snyder, Charlie Cobb, and Ken Wilson, and the technical support provided by Harold Nester, Chuck Miller, and William Saville. Assistance provided by Gary Brauning, Gwenn Catterfeld, Rebecca Cornman, David Griffith, Beth Keene, Janeen Lewis, and Kristi Seat during the collection periods and sample analysis is sincerely appreciated.

\section{REFERENCES}

Apsimon, H. M., M. Kruse, and J. N. B. Bell. 1987. Ammonia emissions and their role in acid deposition. Atoms. Environ. 21:1939-1946. 
Axe, D. E., K. K. Bolsen, D. L. Harmon, R. W. Lee, G. A. Milliken, and T. B. Avery. 1987. Effect of wheat and high moisture sorghum grain fed singly and in combination on ruminal fermentation, solid liquid flow, site and extent of digestion and feeding performance of cattle. J. Anim. Sci. 64:897-906.

Beardsworth, L. J., P. M. Beardsworth, and A. D. Care. 1989. The effect of ruminal phosphate concentration on the absorption of calcium, phosphorus and magnesium from the reticulo-rumen of the sheep. Br. J. Nutr. 61:715-723.

Clark, J. H., T. H. Klusmeyer, and M. R. Cameron. 1992. Microbial protein synthesis and flows of nitrogen fractions to the duodenum of dairy cows. J. Dairy Sci. 75:2304-2323.

Dhiman, T. R., M. S. Zaman, I. S. MacQueen, and R. L. Boman. 2002. Influence of corn processing and frequency of feeding on cow performance. J. Dairy Sci. 85:217-226.

Enivironmental Protection Agency. 1998. National Air Pollutant Emission Trends, 1990-1998. Environmental Protection Agency, Washington, DC.

Frank, B., and C. Swensson. 2002. Relationship between content of crude protein in rations for dairy cows and milk yield, concentration of urea in milk and ammonia emissions. J. Dairy Sci. 85:1829-1838

Guyton, A. D., J. M. McKinney, and K. F. Knowlton. 2003. The effect of steam flaked or ground corn and supplemental phytic acid on phosphorus partitioning and ruminal phytase activity in lactating cows. J. Dairy Sci. 86:3972-3982.

Hall, O. G., H. D. Baxter, and C. S. Hobbs. 1961. Effect of phosphorus in different chemical forms on in vitro cellulose digestion by rumen microorganisms. J. Anim. Sci. 20:817-819

James, T., D. Meyer, E. Esparza, E. J. DePeters, and H. Perez-Monti. 1999. Effects of dietary nitrogen manipulation on ammonia volatilization from manure from Holstein heifers. J. Dairy Sci. 82:2430-2439

Jonker, J. S., R. A. Kohn, and R. A. Erdman. 1998. Using milk urea nitrogen to predict nitrogen excretion and utilization efficiency in lactating dairy cows. J. Dairy Sci. 81:2681-2692.

Kauffman, A. J., and N. R. St-Pierre. 2001. The relationship of milk urea nitrogen to urine nitrogen excretion in Holstein and Jersey cows. J. Dairy Sci. 84:2284-2294.

Knowlton, K. F., B. P. Glenn, and R. A. Erdman. 1998. Performance, rumen fermentation, and site of starch digestion in early lactation cows fed corn grain harvested and processed differently. J. Dairy Sci. 81:1972-1984

Kohn, R. A., Z. Dou, J. D. Ferguson, and R. C. Boston. 1997. A sensitivity analysis of nitrogen losses from dairy farms. J. Environ. Manage. 50:417-428.

Kohn, R. A., K. F. Kalscheur, and E. Russek-Kohn. 2002. Evaluation of models to estimate urinary nitrogen and expected milk urea nitrogen. J. Dairy Sci. 85:227-233.

Kotarski, S. F., R. D. Waniska, and K. K. Thurn. 1992. Starch hydrolysis by the rumen microflora. J. Nutr. 122:178-190.

Likens, G. E., C. T. Driscoll, and D. C. Busco. 1996. Long term effects of acid rain: Response and recovery of a forest ecosystem. Science 272:244-246.
Marini, J. D., and M. E. Van Amburgh. 2003. Nitrogen metabolism and recycling in Holstein heifers. J. Dairy Sci. 81:545-552.

Murphy, M. R., C. L. Davis, and G. C. McCoy. 1983. Factors affecting water consumption by Holstein cows in early lactation. J. Dairy Sci. 66:35-38.

National Research Council. 1989. Nutrient Requirements of Dairy Cattle. 6th rev. ed. Natl. Acad. Sci., Washington, DC.

National Research Council. 2003. Air Emissions from Animal Feeding Operations: Current Knowledge, Future Needs. National Academic Press, Washington, DC.

Nocek, J. E. 1987. Characterization of in situ dry matter nitrogen digestion of various grain forms. J. Dairy Sci. 70:2291-2301.

Orskov, E. R., C. Fraser, V. C. Mason, and S. O. Mann. 1970. Influence of starch digestion in the large intestine of sheep on caecal fermentation, caecal microflora and faecal nitrogen excretion. Br. J. Nutr. 24:671-682.

OSHA. Occupational Safety and Health Standards. Toxic and Hazardous Substances, Standard Number: 1910.1000 TABLE Z-1 Limits for Air Contaminants. US Department of Labor, Washington, DC.

Plascencia, A., and R. A. Zinn. 1996. Influence of flake density on the feeding value of steam-processed corn in diets for lactating cows. J. Anim. Sci. 74:310-316.

Prigge, E. C., R. R. Johnson, F. N. Owens, and D. E. Williams. 1976. Utilization of nitrogen from ground high moisture and dry corn by ruminants. J. Anim. Sci. 43:705-711.

SAS User's Guide Statistics, Version 8.0 Edition. 1999. SAS Inst., Inc., Cary, NC

Shirazi-Beechey, S. P., R. B. Beechey, J. Penny, S. Vayro, W. Buchan, and D. Scott. 1991. Mechanisms of phosphate transport in sheep intestive and parotid gland: Response to variation in dietary phosphate supply. Exp. Physiol. 76:231-241.

Streeter, M. N., D. G. Wagner, F. N. Owens, and C. A. Hibberd. 1989. Combinations of high moisture harvested sorghum grain and dryrolled corn: Effects on site and extent of digestion in beef steers. J. Anim. Sci. 67:1623-1633.

Theurer, C. B., O. Lozano, A. Alio, A. Delgado-Elorduy, M. Sadik, J. T. Huber, and R. A. Zinn. 1999. Steam-processed corn and sorghum grain flaked at different densities alter ruminal, small intestinal, and total tract digestibility of starch by steers. J. Anim. Sci. 77:2824-2831.

Tomas, F. M. 1973. Parotid salivary secretion in sheep: Its measurement and influence on phosphorus in rumen fluid. Q. J. Exp. Physiol. 58:131-138.

Wilkerson, V. A., B. P. Glenn, and K. R. McLeod. 1997. Energy and nitrogen balance in lactating cows fed diets containing dry or high moisture corn in either ground or rolled form. J. Dairy Sci. 80:2487-2496.

Woodford, S. T., M. R. Murphy, and C. L. Davis. 1984. Water dynamics of dairy cattle as affected by initiation of lactation and feed intake. J. Dairy Sci. 67:2336-2343.

Zinn, R. A., C. F. Adam, and M. S. Tamayo. 1995. Interaction of feed intake level on comparative ruminal and total tract digestion of dry-rolled and steam-flaked corn. J. Anim. Sci. 73:1239-1245. 